Yurii Cheban, PhD student,

Department of Theory and Methods of Practical Psychology, The State institution "South Ukrainian National Pedagogical University named after K. D. Ushynsky", 26, Staroportofrankivska Str., Odessa, Ukraine

\title{
RESEARCH METHODS OF EMOTIONAL AND VOLITIONAL POTENTIAL OF HIGHLY QUALIFIED ROWING ATHLETES
}

The article presents the results of theoretical and empirical study of the issue of diagnosing the level of development of emotional and volitional potential of highly qualified rowing athletes in kayaking and canoeing. The relevance of the research topic is determined by the importance of emotional and volitional training of athletes to achieve maximum results in sports competitions. The psychological diagnosis of emotional and volitional potential is a necessary component of such training. The aim of the article is to explore the possibilities of psychological diagnosis of the development level of emotional and volitional potential of highly qualified rowing athletes. It is proposed to use four types of methods to study the emotional and volitional potential. The first one includes methods for determining the values of the available emotional and volitional potential on the basis of self-assessment and expert assessment and those which are based on certain specific test to determine the data of its reserve. The second one is focused on the diagnosis of various emotional and volitional personality traits such as emotionality, emotional maturity, anxiety, emotional stability, confidence, perseverance, self-control, etc. The third one includes methods of assessing such personal characteristics as achievement motivation; the level of development of cognitive processes, characterological features, as well as certain individual and dynamic data. The fourth one includes means of assessing the skills and abilities of self-stabilization in the prestarting situation and in the process of solving a competitive issue. The results of approbation the first type of methods showed that the data obtained through expert assessment of emotional and volitional potential of athletes, selfassessment of athletes own potential and testing the emotional and volitional capabilities during physi-cal exercises correspond to the objective achievements of rowers in sporting competitions and their sport qualifications. However, most of all it concerns the expert assessment.

Keywords: volitional qualities, emotional qualities, highly qualified rowing athletes, athletic activities, emotional and volitional potential.

Подано до редакиії 29.02.2020

УДК: 159.942:159.925

DOI: https://doi.org/10.24195/2414-4665-2020-1-3

\begin{abstract}
Олексій Чебикін,
доктор психологічних наук, академік НАПН Украӥни,

Державний заклад «Південноукрайнський наџіональний педагогічний університет імені К. Д. Ушинського», вул. Старопортофранківська, 26, м. Одеса, Украӥна
\end{abstract}

\section{ЕМОЦЙНИЙ ІНТЕЛЕКТ, ЙОГО ПІЗНАВАЛЬНО-МИСЛЕННЕВІ ОЗНАКИ ТА ФУНКЦІЇ}

В представленій статті зроблено спробу виділити пізнавально-мисленнєві ознаки емоційного інтелекту та їх функції в цььому процесі. Показано, щчо значна частина фахівців, не зважаючи на декларативну відповідність изього феномену до сфери емоцій та інтелекту, аналізує в якості предмета його дослідження соиіальний інтелект та його комунікативні ознаки, емочійну зрілість та їі складові, саморегуляцію, емпатію, експресивність емоцій та ін. Можна припустити, щчо в такому випадку ознаки емоџійного інтелекту підміняються тими, які відносяться до предмету дослідження інших психологічних явищ. Також слід погодитися, щзо всі психічні явища тісно пов'язані між собою, тим більще, щзо емоиії приречено зінтегровані фактично в кожний проиес. Але коли ми обираємо предметом дослідження емоційний інтелект, то природньо мова повинна йти про ті його ознаки, які в більшій мірі повинні відображати певні специфічні особливості емоцій в інтелекті. Запропоновано розглядати емоційний інтелект як психологічну властивість особистості, що характеризується проявом складних немов зінтегрованих, емоиійно-пізнавальних та мисленнєвих особливостей, завдяки яким 
вона досягає своєї мети у вирішенні певних задач/проблем у різних видах діяльності. При иьому можна стверджувати, щуо в емоційному інтелекті емоції в більшій мірі зінтегровані з пізнавальною діяльністю, а інтелект з мисленнєвою. Тобто особливості функціонування базових (простих) емоцій у вищих пізнавальних, зінтегрованих з мисленнєвою діяльністю, вірогідно, і є те, щзо може характеризувати психологічну сутність змісту емоиійного інтелекту. До таких вищих емоційно-пізнавальних особливостей, які супроводжують цеей процес, можна віднести: здивування, цікавість, допитливість, інтерес, наснагу, натхнення, здогадку, розчарування, сумнів, осяяння, еврику та ін. Прояв вказаних ознак може супроводжуватися певними функиіями на рівні комфортності емочійного забарвлення процесу вирішення проблеми, емочійного наведення на спосіб вирішення проблеми, емоційної активації у вигляді посилення чи послаблення прояву цзього процесу, емоційної регуляиії як динаміки зміни руху наведених ознак в процесі рішення проблеми та ін. Побудовано комплекс з трьох методик: дослідження ознак емоційного інтелекту; вивчення прояву простих емоцій в змісті вищих віднесених до ознак емоичійного інтелекту; вивчення виділених функцій ознак емоційного інтелекту. Показано, щзо прослідковується як певна тенденція в прояві ознак емочійного інтелекту, так і його невід'ємних складових простих емоцій в процесі вирішення задачі. Розкрито, щзо емоційно позитивна орієнтація змісту таких ознак емоційного інтелекту як иікавість, осяяння, еврика, їх зв'язок із радістю та функиіями комфортності емоційного наведення, емоційної активації та регуляиії, формують периий симптомокомплекс емоиійного інтелекту. Другий симптомокомплекс формується на базі таких ознак емоційного інтелекту як допитливість, здогадка та сумніву. Третій - иікавості, наснаги та розчарування. Наведені комплекси можуть виступити тими специфічними детермінантами прояву емоиійного інтелекту, а також психологічними характеристиками вірогідних його типових проявів у людини.

Ключові слова: емоції, інтелект, пізнавальні емоційно-мисленнєві особливості, функиії, симптомокомплекси, ознаки емочійного інтелекту.

\section{блеми}

Вступ та сучасний стан досліджуваної про-

Сучасна психологічна наука відносить емоційну сферу особистості до однієї з найбільш актуальних дослідницьких проблем як в теоретичному, так і емпіричному аспектах. В останні роки активізувалися дослідження так званих складних вищих емоційних особливостей особистості (почуттів), в тому числі змісту емоційного інтелекту. Пізнання даного феномену привертає увагу вчених, які по різному розкривають основи його змісту (Андреєва, 2011; Вайсбах, Дакс, 1988; Гоулман, 2011; Моргун, 2010; Носенко, 2004; Робертс, 2004; Чебикін, 2009; Дерев'янко, Примак, Ющенко, 2018; Віlous, Pysarenko, 2016 та ін.). Узагальнення цих та інших досліджень засвідчує, що незважаючи на високу увагу до пізнання емоційного інтелекту залишається ще багато нез'ясованих як теоретичних основ, так й емпіричних даних відносно його характеристики. Особливо це стосується визначення адекватного предмету дослідження, а саме сутності та змісту специфічних ознак емоційного інтелекту. Очевидно, що в цьому випадку мова повинна йти про ті ознаки, які безпосередньо відносяться до емоційної та інтелектуально-мисленнєвої сфери, відображаючи цілісне уявлення про дане явище (Тихоміров, 1984).

Спираючись на викладену позицію, нами була поставлена мета провести дослідження, спрямоване на визначення специфічних ознак емоційного інтелекту. В цьому випадку ознаки ми розглядаємо як невід'ємні складові певної психологічної властивості, що характеризують ії специфічну природу та відрізняє від інших.

При цьому були поставлені наступні завдання. По-перше, уточнити змістову основу емоційного інтелекту та визначити перелік найбільш вірогідних ознак, які можуть характеризувати цей феномен. По-друге, побудувати комплекс пошукових методик, які б дозволяли досліджувати саме емоційно-інтелектуальні ознаки. Потретє, дослідити особливості прояву таких ознак при вирішенні особистістю задачі чи проблеми. По-четверте,
Introduction and the current state of the issue

Modern psychological science refers the emotional sphere of individual to one of the most pressing study problems in both theoretical and empirical aspects. In recent years, the study of the so-called complex higher emotional features of individual (feelings) including the content of emotional intelligence has been increased. The cognition of this phenomenon attracts attention of scientists, who in different ways reveal the basics of its content (Andreeva, 2011; Weisbach, Dax, 1988; Goulman, 2011; Morgun, 2010; Nosenko, 2004; Roberts, 2004; Chebykin, 2009; Derevyanko, Primak, Yushchenko, 2018; Bilous, Pysarenko, 2016, etc.). The generalization of these and other studies shows that despite the high level of attention to the cognition of emotional intelligence, there are still many unexplained both theoretical and empirical data on its characteristics. This is especially true of determining the adequate subject of study, namely the nature and content of specific signs of emotional intelligence. This obviously should refer to those signs in this case that are directly related to the emotional and intellectual-mental sphere, reflecting a holistic view of the phenomenon (Tikhomirov, 1984).

Based on the above position, the aim was to conduct study pointed at identifying specific signs of emotional intelligence. In this case, the signs are considered as integral components of a certain psychological property that characterize its specific nature and distinguish it from others.

The following tasks were set: first, to clarify the semantic basis of emotional intelligence and determine the list of the most probable signs that can describe this phenomenon; secondly, to build a complex of exploratory techniques that would allow to explore the emotional and intellectual characteristics; third, to explore the features of the manifestation of such signs in solving an individual's task or problem; fourth, to find out to what extent simple or basic emotions can determine the manifestation of complex or higher intellectual and emotional signs in the cognitive process of the individual; fifth, to investigate the 
3'ясувати в якій мірі прості чи базові емоції можуть детермінувати прояв складних чи вищих інтелектуальноемоційних ознак в пізнавальному процесі особистості. По-п’яте, дослідити характер прояву функцій емоційноінтелектуальних ознак, що мають місце в пізнавальному процесі.

Внаслідок узагальнення теоретичних та пошуково-емпіричних досліджень, присвячених проблемі емоційного інтелекту, було встановлено, що переважна більшість фахівців, не зважаючи на декларативну відповідність цього феномену до сфери емоцій та інтелекту, аналізує в якості предмета досліджень різні ознаки. Як правило вивчаються особливості, які нібито відображають емоційний інтелект, а насправді соціальний інтелект та його комунікативні ознаки, емоційну зрілість та такі її ознаки: експресивність - адекватне відображення власних зовнішніх проявів емоцій, а також розпізнавання їх у інших та вплив на них; саморегулящію - адекватне керування власними емоціями, а також емоціями інших людей; емпатія - адекватне власне співчуття іншим людям, а також сприйняття цього процесу у них та влив на нього (Чебикін, 1997; Чебикін, 2009; Chebykin, Kosianova, 2017 та ін.). Можна в цьому випадку говорити, що особливості емоційного інтелекту підміняються ознаками, які відносяться до предмету досліджень інших явищ. В такому випадку дуже проблемними виступають подібні результати досліджень емоційного інтелекту. Враховуючи, що послідовники вказаних підходів беруть свої ознаки за основу характеристики емоційного інтелекту, нерідко пропонуючи відповідні технології його діагностики. В сучасній психологічній науці відсутне однозначне тлумачення самого інтелекту, оскільки він достатньо тісно поєднується 3 мисленням. В цьому аспекті маються спрощенні позиції фахівців розглядати інтелект як здатність до мислення, а останнє як процес реалізації інтелекту. Саме тому переважна частина дослідників, при розробці тестів оцінки інтелекту, за основу бере саме дані мисленнєвої сфери людини. Можна погодитися, що всі психічні явища тісно пов'язані між собою, тим більше, що емоції приречено зінтегровані фактично в кожний процес. Ніхто не буде суперечити, що виокремити їх повністю 3 якогось процесу надзвичайно складно. Однак наука диференціює структурні компоненти психіки, ії властивості, процеси, стани, якості, які мають свої ключові специфічні складові. Очевидно, що ключовим в пізнанні змісту цього феномену, виходячи з його назви, повинні виступати саме особливості емоцій та мислення, що реалізуються в пізнавальній діяльності людини.

Відомо, що переважна більшість вчених виділяють базові немов первинні емоції (радість, страх, гнів та ін.), які імплементуються в певному співвідношенні в складних чи вищих емоційних особливостях особистості (почуттях). Останні мають свою змістову специфіку в залежності від особистості, наприклад, моральні або ті, що пов'язані з конкретною діяльністю (наприклад: 3 мистецькою, спортивною, інтелектуальною та ін.). Саме тому, коли ми обираємо предметом дослідження емоційний інтелект, то природньо мова повинна йти про ті його ознаки, які в більшій мірі повинні відображати специфічні особливості емоцій в інтелекті. Спираючись на вищенаведене у нашому дослідженні, nature of the manifestation of the functions of emotional and intellectual signs in the cognitive process.

As a result of generalization of theoretical and exploratory study on the problem of emotional intelligence, it was found that the vast majority of experts, despite the declarative relevance of this phenomenon to the field of emotions and intelligence, analyzes various signs as a subject of study. As a rule, the features that supposedly reflect emotional intelligence are studied, but in fact it is the social intelligence and its communicative signs, emotional maturity and its following signs: expressiveness - adequate reflection of own external manifestations of emotions, as well as recognizing them in others and influencing them; self-regulation - adequate control of one's own emotions and the emotions of other people; empathy - adequate self-compassion for other people, and the perception of this process in them and the influence on it (Chebykin, 1997; Chebykin, 2009; Chebykin, Kosianova, 2017, etc.). It can be stated that in this case the features of emotional intelligence are replaced by signs that relate to the subject of study of other phenomena. In this case, such results of studies of emotional intelligence are very problematic. According to the fact that the followers of these approaches take their signs as a basis for the characteristics of emotional intelligence, they often offer appropriate technologies for its diagnosis. In modern psychological science there is no unambiguous interpretation of the intelligence, because it is quite closely combined with thinking. In this aspect, there are simplified positions of experts to consider intelligence as the thinking capacity and thinking as a process of realization of intelligence. That is why the vast majority of researchers in the development of intelligence tests are based on data of the human mental sphere. One can agree that all mental phenomena are closely related, especially since emotions are integrated actually into every process. No one will argue that it is extremely difficult to separate them completely from a process. But science differentiates the structural components of the psyche, its properties, processes, states, qualities, which have their key specific components. It is obvious that the key in understanding the content of this phenomenon, based on its name, should be the features of emotions and thinking, which are realized in the cognitive activity of person.

It is known that the vast majority of scientists identify basic sort of primary emotions (joy, fear, anger, etc.), which are implemented in a certain ratio in the complex or higher emotional features of individual (feelings). The latter have their own specifics depending on the individual, for example, moral or those related to a particular activity (for example: artistic, sports, intellectual, etc.). That is why, when the emotional intelligence is chosen as the subject of study, the discussion should cover its features, which should more reflect the specific features of emotions in the intelligence. Based on the above in our study, we will adhere to the definition of emotional intelligence as a psychological property of the individual, characterized by the manifestation of complex sort of (integrated) cognitive-emotional and mental features, due to which it achieves its goal in certain tasks/problems solving in various activities. 
ми будемо дотримуватись визначення емоційного інтелекту як психологічної властивості особистості, що характеризується проявом складних немов (зінтегрованих) пізнавально-емоційних та мисленнєвих особливостей, завдяки яким вона досягає своєї мети у вирішенні певних задач/проблем в різних видах діяльності.

В цьому аспекті маються лише поодинокі дослідження (Васіл'єв, 1998; Тихоміров, 1984; Чебикін, 1992 та ін.), в яких зосереджується увага саме на пізнавальних особливостях емоційної сфери, які супроводжують мисленнєвий процес. До останніх можна віднести складні або вищі емоційно-пізнавальні особливості як вірогідні специфічні ознаки емоційного інтелекту, наприклад, здивування, цікавість, допитливість, інтерес, наснага, натхнення, здогадка, розчарування, сумнів, осяяння, еврика та ін. Крім того, як свідчать дослідження (Тихоміров, 1984), до змісту однієї з наведених ознак в пізнавальній діяльності можуть входити в певному співвідношенні прояви інших віднесених нами до цього класу, характеризуючи не тільки таку їх зінтегрованість, але й механізми динаміки та єдності в процесі вирішення задачі. Ми також усвідомлюємо, що наведені ознаки, поєднуючи в собі емоційно-пізнавальні та мисленнєві особливості, можуть характеризувати прямо чи опосередковано зміст не тільки емоційного інтелекту, а й інших властивостей психіки. В той же час, на наше переконання, їх прояв в певному співвідношенні як окремо, так і в цілому в процесі вирішення різних задач/проблем в найбільшій мірі може розкривати саме психологічну специфіку емоційного інтелекту як психологічної властивості особистості. Прояв вказаних ознак також може супроводжуватися певними функціями різних особливостей на рівні: комфортності емоційного забарвлення процесу вирішення проблеми; емоційного наведення на спосіб вирішення проблеми; емоційної активації - посилення чи послаблення прояву цього процесу; емоційної регуляції як динаміки зміни руху наведених ознак в процесі рішення проблеми. Наведені результати про виділені емоційно-інтелектуальні ознаки на різних етапах вирішення проблеми, вірогідна їх детермінація базовими емоціями та функціональні особливості, які при цьому можуть реалізовуватися в мисленнєвому процесі, потребують експериментального підтвердження. Саме ці позиції, на нашу думку, можуть бути однією 3 методологічних основ пізнання феномену емоційного інтелекту.

При цьому можна стверджувати, що в емоційному інтелекті емоції в більшій мірі зінтегровані з пізнавальною діяльністю, а інтелект з мисленнєвою діяльністю особистості. Тобто особливості вираження, функціонування базових емоцій у вищих пізнавальних зінтегрованих з мисленнєвою діяльністю, вірогідно, і є те, що може характеризувати психологічну сутність змісту емоційного інтелекту. Наведені дані по суті є тими визначальними та специфічними ознаками, які в найбільшій мірі можуть характеризувати саме предмет дослідження емоційного інтелекту. Слід також додати, що вказані ознаки дозволяють аналізувати емоційний інтелект на рівні різних етапів вирішення тієї чи іншої проблеми. Розгортання процесу вирішення певної проблеми може передбачити етап первинного іiі сприй-
In this aspect, there are only a few studies (Vasiliev, 1998; Tikhomirov, 1984; Chebykin, 1992, etc.), which focus on the cognitive features of the emotional sphere that accompany the thinking process. The latter include complex or higher emotional and cognitive features as probable specific features of emotional intelligence, such as surprise, curiosity, inquisitiveness, interest, enthusiasm, inspiration, guess, disappointment, doubt, insight experience, eureka, and others. Furthermore, according to the study (Tikhomirov, 1984), the content of one of these features in cognitive activity may include a certain ratio of manifestations of others which we include in this classification, characterizing not only their integration, but also the mechanisms of dynamics and unity in the tasks solving. It is also understood that these signs, combining emotional-cognitive and mental features, can describe directly or indirectly the content of not only emotional intelligence, but also other properties of the psyche. At the same time, in our opinion their manifestation in a certain ratio, both individually and as a whole in the process of solving various tasks/problems can more reveal the psychological specificity of emotional intelligence as a psychological property of the individual. The manifestation of these signs may also be accompanied by certain functions of different features at the level of: comfort of emotional coloring of the problem-solving process; emotional guidance on how to solve the problem; emotional activation - strengthening or weakening the manifestation of this process; emotional regulation as the dynamics of changes in the movement of these signs in the problemsolving process. The presented results of the selected emotional and intellectual signs at different stages of problem solving, their probable determination by basic emotions and functional features, which can be realized in the thinking process, require the experimental confirmation. From our point of view, these positions can be one of the methodological bases of cognition of the phenomenon of emotional intelligence.

It can be argued that emotions are more integrated with cognitive activity in emotional intelligence, and intelligence with the mental activity of the individual, that is, the features of expression and functioning of basic emotions in higher cognitive integrated with mental activity, and probably that's what something that can characterize the psychological essence of the content of emotional intelligence. These data are essentially the defining and specific signs that can more characterize the subject of the study of emotional intelligence. It should also be added that these signs allow to analyze the emotional intelligence at the level of different stages of problem solving. The initiating process of certain problem solving can involve the stage of its initial perception, the stage of finding solutions and the stage of its solution (Tikhomirov, 1984; Chebykin, 1992, etc.), in which such mental operations as analysis, synthesis, generalization, etc. are realized. It is obvious, that the manifestation of signs both procedurally variable and relatively stable, based on the social nature of this phenomenon should be taken into account in the study of emotional intelligence.

Research methods

It is understood that the way of creating a reliable 
няття, етап пошуку способів вирішення та етап іï вирішення (Тихоміров, 1984; Чебикін, 1992 та ін.), в яких відповідно реалізуються такі мисленнєві операції як аналіз, синтез, узагальнення та ін. Очевидно, при дослідженні емоційного інтелекту, слід враховувати прояв ознак як процесуально-перемінних, так і відносно стійких, спираючи на соціальну природу цього феномену.

\section{Методи дослідження}

Ми усвідомлюємо, що шлях створення надійної та валідної методики діагностики емоційного інтелекту людини довготривалий та потребує різних попередніх досліджень, які б дали підгрунтя для визначення та перевірки задекларованої стратегії. Саме тому на цьому попередньому етапі ми спрямували свої зусилля на побудову пошукових методик, які були зорієнтовані на вивчення виділених ознак емоційного інтелекту, базових емоцій та механізмів, які можуть характеризувати процес емоційного інтелекту.

Внаслідок виконаної роботи нами було побудовано три такі взаємопов'язані методики. Перша методика спрямовувалася на вивчення прояву ознак емоційного інтелекту на різних етапах вирішення певної задачі. При цьому ми виходили 3 припущення, що дані, отримані завдяки такої процедури, будуть більш інформативними як в цілому, так і з урахуванням етапів вирішення інтелектуальної задачі. При розробці такої методики урахувалися як наведені результати досліджень, так й інші дані (Тихоміров, 1984; Чебикін, 1992 та ін.), в наслідок чого нами був уточнений зміст виділених ознак емоційного інтелекту, які можуть характеризувати даний феномен в пізнавально-мисленнєвій діяльності людини при вирішенні певної проблеми. Виконане дослідження дозволило розглядати: здивування як емоційно-інтелектуальну реакцію від несподіваного, дивного, незрозумілого при сприйнятті проблеми; цүікавicmb як емоційно-інтелектуальне прагнення долучитися до пізнання проблеми; допитливість як емоційноінтелектуальне зосередження на уточненні змісту проблеми; інтерес як емоційно-інтелектуальну мотивацію, спрямовану на вирішенні проблеми; наснагу як емоційно-інтелектуальне задоволення, пов'язане 3 процесом рішення проблеми; натхнення як емоційно-інтелектуальну мобілізацію у вигляді яскравих образів, уявлень при вирішенні проблеми; здогадку як емоційно-інтелектуальну прогностичну оцінку пов'язану з уловлюванням способів рішення проблеми; розчарування як пригнічення емоційно-інтелектуального стану, пов'язаного зі складнощами вирішення проблеми; сумнів як емоційно-інтелектуальне напруження пов'язане з пошуком дій рішення проблеми; осяяння як емоційно-інтелектуальне задоволення від визначення способу рішення проблеми; еврика як емоційно-інтелектуальний підйом від несподіваного знаходження способу вирішення складної проблеми.

У конструкції побудованої методики у вигляді опитування передбачалось кожному випробуваному оцінити власний, відносно типовий рівень вираженності наведених емоційно-інтелектуальних ознак на етапі: первинного сприйняття проблеми; пошуку способів іï вирішення та на етапі вирішення. Кожному випробуваному потрібно було на умовній шкалі від (min) 0 балів and valid method of diagnosing a person's emotional intelligence takes a long time and requires various preliminary studies that would provide a basis for defining and verifying the approved strategy. That is why at this preliminary stage the efforts were focused on building search techniques that aimed at the study of selected signs of emotional intelligence, basic emotions and mechanisms that can describe the process of emotional intelligence.

As a result of the work, three interrelated techniques have been developed. The first technique was aimed at studying the manifestation of signs of emotional intelligence at different stages of solving certain task. In this case, the data obtained through such a procedure will be more informative both in general and taking into account the stages of solving the intellectual task. In developing such a technique, both the results of the study and other data (Tikhomirov, 1984; Chebykin, 1992, etc.) were taken into account. As a result, the content of selected signs of emotional intelligence that can describe this phenomenon in human cognitive and mental activity in problem solving was clarified. The study allowed to consider: surprise as emotional and intellectual reaction to the unexpected, strange, incomprehensible in the perception of the problem; curiosity as emotional and intellectual desire to join the cognition of the problem; inquisitiveness as emotional and intellectual focus on the content clarification of the problem; interest as emotional and intellectual motivation aimed at problem solving; enthusiasm as emotional and intellectual satisfaction associated with the problem-solving process; inspiration as emotional and intellectual mobilization in the form of vivid images, ideas in the problem solving; guess as emotional-intellectual prognostic assessment associated with catching the ways of the problem solving; disappointment as suppression of the emotional and intellectual state associated with the difficulties of the problem solving; doubt as emotional and intellectual stress which is associated with finding problem solutions; insight experience as emotional and intellectual pleasure from determining the way of problem solving; eureka as emotional and intellectual lift from unexpected finding a way of complex problem solving.

In the construction of this technique in the form of a survey, each subject was supposed to assess their own, relatively typical level of expression of the given emotional and intellectual signs at the stage of: initial perception of problem; finding the ways to solve it and at the stage of its solving. Each subject had to mark the inherent level of severity of the diagnosed signs on the scale from $(\min ) 0$ points to $(\max ) 10$ points. During processing, the results obtained in the final version were presented in the form of a 10-point scale.

The second technique was a questionnaire aimed at studying the manifestation of such basic emotions as joy, fear, anger in the content of the selected signs of emotional intelligence. The subjects had to note in a special form to what extent these emotions are manifested in the signs of emotional intelligence from $(\mathrm{min}) 0$ points to $(\max ) 10$ points in the problem solving. During processing, the obtained results were also presented in the form of a 10-point scale. 
до (max) 10 балів відмітити притаманний рівень вираженості діагностованих ознак. При обробці отримані результати в остаточному варіанті презентувалися у вигляді 10-бальної шкали.

Друга методика уявляла собою опитувальник, направлений на дослідження прояву таких базових емоцій як радість, страх, гнів в змісті виділених ознак емоційного інтелекту. Випробуваним потрібно було відмітити в спеціальному бланку в якій мірі проявляються вказані емоції в ознаках емоційного інтелекту від (min) 0 балів до (max) 10 балів при вирішенні проблеми. При обробці отримані результати презентувалися теж у вигляді 10бальної шкали.

Третя методика, як і попередні, мала вигляд опитувальника, спрямованого на дослідження прояву виділених функцій ознак емоційного інтелекту, а саме комфортністі емоціонального забарвлення процесу вирішення проблеми; емоційного наведення на спосіб вирішення проблеми; емоційної активації у вигляді посилення чи послаблення процесу вирішення задачі; емоційної регуляції на рівні динаміки змін руху наведених ознак в процесі вирішення проблеми.

Випробуваним потрібно було відмітити в спеціальному бланку в якій мірі перелічені функції проявляються в змісті ознак емоційного інтелекту при вирішенні проблеми від (min) 0 балів до (max) 10 балів. При обробці отримані результати, аналогічно як у попередніх методиках, оформлювалися в межах 10-бальної шкали. Слід зазначити, що обрана однотипна процедура підходу до оцінки прояву перелічених особливостей орієнтована на оптимізацію дій випробуваних при виборі відповіді.

У якості випробуваних була обрана група, що включала 30 магістрів-психологів, які в певній мірі вже володіють основами психологічної компетентності, відносно змісту емоцій, мислення та інтелекту. В даному випадку ми обрали їх як певну експертну групу, щоб більш детально з'ясувати можливості запропонованого комплексу методичних процедур, які в майбутньому можуть виступати основою для однієї комплексної методики дослідження емоційного інтелекту на різних вибірках випробуваних.

\section{Результати досліджень та їх аналіз}

Розглядаючи отримані результати можна відмітити, що в межах 10-бальної шкали діагностовані показники ознак емоційного інтелекту мають достатньо незначну варіативність, яка коливається в межах від 3,0 до 7,0 балів. При цьому на кожному етапі вирішення проблеми в комплексі з іншими діагностованими емоційномисленнєвими ознаками емоційного інтелекту провідними виступали: на першому етапі вирішення проблеми - інтерес (6,9 бал.); натхнення (6,8 бал.); допитливість (5,9 бал.). На другому етапі - інтерес (6,8 бал.); здогадка (6,4 бал.), допитливість (6,3 бал.). На третьому етапі здогадка (6,7 бал.); інтерес (6,2 бал.); еврика (6,1 бал.). Виходячи 3 наведеного можна відмітити, що на кожному етапі вирішення проблеми маються свої характерні комплекси домінуючих діагностованих ознак емоційного інтелекту. Якщо розглядати за аналогічними ознаками узагальнені результати, що характеризують всі три етапи, то можна відмітити, що цей комплекс
The third technique, like the previous ones, took the form of a questionnaire aimed at studying the manifestation of the selected functions of the signs of emotional intelligence, namely the comfort of emotional coloring of the problem-solving process; emotional guidance on how to solve the problem; emotional activation in the form of strengthening or weakening of problem-solving process; emotional regulation at the level of the dynamics of changes in the movement of these signs in the problemsolving process.

The subjects had to note in a special form to what extent these functions are manifested in the content of signs of emotional intelligence in problem solving from (min) 0 points to $(\max ) 10$ points. During processing, the results obtained in the same way as in previous methods, were drawn up in the form of a 10-point scale. It should be noted that the selected same-type procedure of the approach to the assessment of the manifestation of the listed features was focused on optimizing the actions of the subjects when choosing the answer.

A group of 30 Masters of Psychology was selected as subjects, who already have the basics of psychological competence in the content of emotions, thinking and intelligence. In this case, they were selected as a certain expert group to clarify in more detail the possibilities of the proposed complex of methodological procedures, which in the future can serve as a basis for one comprehensive technique of studying emotional intelligence in different samples of subjects.

\section{Research results and their analysis}

Considering the obtained results, it can be noted that within the 10-point scale the diagnosed indicators of signs of emotional intelligence have a relatively minor variability, which ranges from 3.0 to 7.0 points. Thus at each stage of problem solving in a complex with other diagnosed emotional and mental signs of emotional intelligence the leading ones were the following: at the first stage of problem solving - interest (6,9 points); inspiration (6.8 points); inquisitiveness (5.9 points); at the second stage - interest (6.8 points); guess (6.4 points), inquisitiveness (6.3 points); at the third stage - guess (6.7 points); interest (6.2 points); eureka (6.1 points). Based on the above, it can be noted that at each stage of problem solving there are complexes of dominant diagnosed signs of emotional intelligence. It can be noted that this complex is formed by interest (6.5 points), guess (6.3 points), inquisitiveness (6.0 points) when considered the generalized results that characterize all three stages on similar grounds. It is probable that these emotional and intellectual signs to the considerable degree can not only separately describe the emotional intelligence, but also represent it as a dummy subscript for a given sample.

Regarding the obtained individual data of the manifestation of basic emotions, namely joy, fear and anger, it has been found that the first one occurs in the content of the vast majority of signs of emotional intelligence. This indicator (10 points) acquires the maximum value at the individual level at the manifestation of eureka. In general, the indicators of joy range from 3 points to 10 points. There is also a variability of fear, but to a lesser extent than the previous indicator. Thus, it could not be found in the manifestation of eureka and insight experience at the 
сформували інтерес (6,5 бал.), здогадка (6,3 бал.), допитливість (6,0 бал.). Вірогідно, саме ці емоційно-інтелектуальні ознаки в найбільшій мірі можуть не тільки характеризувати емоційний інтелект окремо, але також представляти його у вигляді умовного індексу для цієї вибірки.

Відносно отриманих індивідуальних даних прояву базових емоцій, а саме радості, страху та гніву було встановлено, що перша має місце в змісті переважної більшості ознак емоційного інтелекту. Максимального значення на індивідуальному рівні цей показник (10 балів) набуває при прояві еврики. В цілому, показники радості коливаються від 3 балів до 10 балів. Що стосується страху, то тут теж спостерігається його варіативність, але в меншій мірі відносно попереднього показника. Так, при прояві еврики, осяяння на індивідуальному рівні він відсутній, а найвищі його значення відмічені в змісті таких ознак емоційного інтелекту при розчаруванні, сумніву (7 балів). Відносно гніву, то він не виявився в прояві здивування та осяяння. Максимальні його значення проявлялися при розчаруванні та натхненні (до 8 балів).

Виходячи $з$ таких попередніх даних можемо припустити, що базові емоції адекватно проявляються в змісті їх складних ознак, що віднесені нами до емоційного інтелекту. Також можно говорити, що радість $\epsilon$ провідною в даному випадку, оскільки має середній показник у змісті ознак емоційного інтелекту в межах від 6,8 балів до 10 балів, на відміну гніву - 3,8 балів та страху - 2,9 балів. Такі дані підтверджують існуючі результати досліджень відносно визначальної ix позиції у відображенні складних чи вищих емоційних переживань. Одночасно вони розширяють існуючі уявлення відносно виділених нами специфічних ознак емоційного інтелекту. В даному випадку ми можемо говорити, що незважаючи на те, що останні сформувалися в значній мірі під впливом різних соціальних умов розвитку випробуваних, базові емоції залишаються тією вихідною платформою, яка для них є важливим підгрунтям в тому числі, коли ми говоримо про прояв інтелекту.

Подальший розгляд отриманих результатів особливостей виділених нами функцій ознак емоційного інтелекту засвідчив, що комфортність емоційного забарвлення достатньо суттєво проявляється на індивідуальному рівні при здивуванні, цікавості, осяянні, насназі, евриці в межах від 9 до 10 балів. Значно нищі значення цієї функції відмічені при допитливості та розчаруванні від 3 до 4 балів. Цікавими для нас виступали результати функції емоціонального наведення на спосіб вирішення задачі. Максимальною ця функція набула на індивідуальному рівні в змісті таких ознак емоційного інтелекту як в здогадці та евриці (9 балів), а мінімальною - при розчаруванні (2 бали). Що стосується функції емоційної активації посилення чи послаблення процесу вирішення задачі, то найбільших значень вона набула в змісті прояву таких ознак емоційного інтелекту як осяянні, натхненні, евриці (до 9 балів), а мінімальною - при розчаруванні (2 бали). Функція емоційної регуляції, що характеризувала динаміку змін руху наведених ознак емоційного інтелекту в процесі вирішення проблеми, набула достатньо високих значень в інтересі, насназі, натхненні, евриці (в межах 9 балів), а дещо в меншій individual level, and its highest values are observed in the content of such signs of emotional intelligence as disappointment, doubt (7 points). As for anger, it did not appear in the manifestation of surprise and enlightenment. Its maximum values were manifested in disappointment and inspiration (up to 8 points).

Based on such preliminary data, it can be assumed that the basic emotions seem to be adequately manifested in the content of their complex signs, which are attributed to emotional intelligence. It can also be stated that joy is leading in this case, because it has an average indicator in the content of signs of emotional intelligence in the range from 6.8 points to 10 points, in contrast to anger -3.8 points and fear -2.9 points. Such data confirm the existing results of the study regarding their position in the reflection of complex or higher emotional experiences. At the same time, they expand the existing ideas about the specific signs of emotional intelligence that we have identified. In this case, it can be stated that despite the fact that the latter were formed largely under the influence of different social conditions of development of subjects, the basic emotions remain the important basis for them, including the fact when it is talked about the intelligence.

The further consideration of the obtained results of the features of the selected functions of signs of emotional intelligence showed that the comfort of emotional coloring is quite significant at the individual level with surprise, curiosity, insight experience, enthusiasm and eureka in the range from 9 to 10 points. The significantly lower values of this function were observed with inquisitiveness and disappointment from 3 to 4 points. The results of the function of emotional guidance on the way of problem solving have been proved interesting for us. This function was the maximum at the individual level in the content of such signs of emotional intelligence as guess and eureka (9 points), and the minimum - disappointment ( 2 points). As for the function of emotional activation, strengthening or weakening the process of problem solving, it acquired the greatest values in the content of the manifestation of such signs of emotional intelligence as insight experience, inspiration, eureka (up to 9 points), and minimal in disappointment (2 points). The function of emotional regulation, which describe the dynamics of changes in the movement of these signs of emotional intelligence in the process of problem solving, has become quite high in interest, enthusiasm, inspiration, eureka (within 9 points), and to a lesser extent - in disappointment (4 points). Based on the average data, it can be noted that the comfort function of emotional coloring in the content of the selected signs in problem solving is dominant (7.2 points). Other functions are also quite significant in the range of $6.4-$ 6.7 points in the content of the selected signs of emotional intelligence.

Thus, the obtained preliminary results give grounds to note that there is a certain tendency both in the manifestation of signs of emotional intelligence and its components of basic emotions. In this case, it can be noted that the emotional and positive orientation of the content of such signs as curiosity, insight experience, eureka, their connection with joy and comfort functions of emotional coloring, emotional guidance, emotional activation and regulation form the first conditional complex. The second 
мірі - в розчаруванні (4 бали). Спираючись на середні дані можна відмітити, що функція комфортності емоційного забарвлення в змісті виділених ознак при вирішенні задачі є домінуючою (7,2 бали). Інші функції теж достатньо суттєво проявляються в межах 6,4 -6,7 балах в змісті виділених ознак емоційного інтелекту.

Таким чином, отримані попередні результати дають підставу відмітити, що прослідковується певна тенденція як в прояві ознак емоційного інтелекту, так і його складових базових емоцій. В даному випадку ми можемо говорити, що емоційно-позитивна орієнтація змісту таких ознак як цікавість, осяяння, еврика, їх зв'язок із радістю та функціями комфортності емоційного забарвлення, емоційного наведення, емоційної активації та регуляції формують перший умовний симптомокомплекс. Другий симптомокомплекс формується на базі таких ознак емоційного інтелекту як допитливості, здогадки, сумніву. Третій - цікавості, наснаги та розчаруванні. Наведені симптомокомплекси можуть бути як тими специфічними детермінантами емоційного інтелекту, так і характеристиками вірогідних його типів у людини.

Таким чином отримані результати виконаного пошукового дослідження дають підставу для проведення поглибленого вивчення цього феномену, зорієнтованого на побудову комплексної методики діагностики емоційного інтелекту з урахуванням змісту його специфічних ознак та їх функцій в процесі рішення тієї чи іншої проблеми. При цьому важливим також постає доповнення методичного інструментарію аналізом інших особливостей емоційної сфери та мисленнєвих операцій, а також розширенням вибірки випробуваних з використанням поглиблених статестичних методів обробки отриманих результатів.

\section{Висновки}

1. Розкрито, що при вивченні емоційного інтелекту фахівці використовують в якості ознак його пізнання різні особливості, які нерідко відносяться до предмету дослідження інших психологічних явищ.

2. Запропоновано розглядати емоційний інтелект як психологічну властивість особистості, що характеризується проявом складних немов зінтегрованих пізнавальних, емоційно-мисленнєвих особливостей, завдяки яким вона досягає своєї мети у вирішенні певних задач/проблем у різних видах діяльності.

3. До виділеного та охарактеризованого комплексу специфічних ознак емоційного інтелекту можна віднести як прості емоції (радість, страх, гнів), так і вищі емоційно-пізнавальні особливості, що зінтегровані з мисленнєвою діяльністю при вирішенні певної задачі, а саме здивування, цікавість, допитливість, інтеpec, наснагу, натхнення, здогадку, розчарування, сумнів, осяяння, еврику. Вірогідними їх функціями у вказаному процесі можуть бути: комфортність емоційного забарвлення процесу вирішення задачі; емоційне наведення на спосіб вирішення задачі; емоційну активацію у вигляді посилення чи послаблення процесу вирішення задачі; емоційну регуляцію як динаміку змін руху наведених ознак в процесі вирішення задачі.

4. Побудовано комплекс методичних процедур, в який увійшли: по-перше, методика дослідження ознак complex is formed on the basis of such signs of emotional intelligence as inquisitiveness, guess, doubt. The third one includes curiosity, enthusiasm and disappointment. The given complexes can be both those specific determinants of emotional intelligence, and characteristics of its human probable types.

Thus, the results of the search provide a basis for indepth study of this phenomenon, focused on building a complex technique for diagnosing emotional intelligence, taking into account the content of its specific signs and their functions in problem-solving process. At the same time, it is also important to supplement the methodological tools with the analysis of other features of the emotional sphere and mental operations, as well as to expand the sample of subjects using in-depth statistical methods of processing the obtained results.

\section{Conclusions}

1. It has been revealed that in the study of emotional intelligence, experts use various features as signs of its cognition, which often relate to the subject of study of other psychological phenomena.

2 . It has been proposed to consider emotional intelligence as a psychological property of individual, characterized by the manifestation of complex sort of integrated cognitive, emotional and mental features, due to which it achieves its goal in certain tasks/problems solving in different activities.

3. The selected and characterized complex of specific signs of emotional intelligence can include both simple emotions (joy, fear, anger) and higher emotional and cognitive features that are integrated with mental activity in problem solving, namely surprise, curiosity, inquisitiveness, interest, enthusiasm, inspiration, guess, disappointment, doubt, insight experience, eureka. Their probable functions in the specified process can be: comfort of emotional coloring of problemsolving process; emotional guidance on how to solve the problem; emotional activation in the form of strengthening or weakening the problem-solving process; emotional regulation as the dynamics of changes in the movement of these signs in the problem-solving process.

4. A set of methodological procedures has been created, which included: first, the method of studying the signs of emotional intelligence; secondly, the method of studying the manifestation of simple emotions in the content of the higher emotions attributed to the signs of emotional intelligence; thirdly, the method of studying the selected functions of the signs of emotional intelligence in the problem-solving process.

5. It has been shown that there is a certain tendency in the manifestation of signs of emotional intelligence, and its integral components of simple emotions in problem-solving process. It has been revealed that the emotional and positive orientation of the content of such signs of emotional intelligence as curiosity, insight experience, eureka, their connection with joy and comfort functions of emotional guidance, emotional activation and regulation form the first complex of emotional intelligence. The second complex is formed on the basis of such signs of emotional intelligence as inquisitiveness, guess and doubt. The third one includes curiosity, enthusiasm and disappointment. These complexes can be those specific 
емоційного інтелекту; по-друге, методика вивчення прояву простих емоцій в змісті вищих віднесених до ознак емоційного інтелекту; по-третє, методика вивчення виділених функцій ознак емоційного інтелекту в процесі вирішення проблеми.

5. Показано, що прослідковується як певна тенденція в прояві ознак емоційного інтелекту, так і його невід'ємних складових простих емоцій в процесі вирішення задачі. Розкрито, що емоційно-позитивна оріснтація змісту таких ознак емоційного інтелекту як цікавість, осяяння, еврика, їх зв'язок із радістю та функціями комфортності емоційного наведення, емоційної активації та регуляції формують перший симптомокомплекс емоційного інтелекту. Другий симтомокомплекс формується на базі таких ознак емоційного інтелекту як допитливість, здогадка та сумніву. Третій - цікавості, наснаги та розчарування. Наведені комплекси можуть виступити тими специфічними детермінантами прояву емоційного інтелекту, а також психологічними характеристиками вірогідних його типових проявів у людини.

\section{Література}

1. Андреева И. Н. Эмоциональный интеллект как феномен современной психологии. Новополоцк: ПГУ, 2011. 388 c.

2. Васильев И. А. Роль интеллектуальных эмоций в регуляции мыслительной деятельности. Психологический журнал. 1998. Т. 19, № 4. С. 49-60.

3. Вайсбах Х., Дакс У. Эмоциональный интеллект. Москва: Лик Пресс, 1988.

4. Гоулман Д. Эмоциональный интеллект / пер. с англ. А. П. Исаевой. Москва: АСТ, Астрель, 2011. 748 c.

5. Дерев’янко С., Примак, Ю., Ющенко І. Роль емоційного інтелекту в запобіганні віктимності молоді. Наука і освіта. 2018. №9-10. С. 44-51.

6. Моргун В. Р. Емоційний інтелект у багатовимірній структурі особистості. Постметодика. 2010. №6(97). С. 2-14.

7. Носенко Е. Л. Емоційний інтелект як соціально значуща інтегральна властивість особистості. Психологія і суспільство. 2004. №4. С. 95-109.

8. Робертс Р. Д. Эмоциональный интеллект: проблемы теории, измерения и применения на практике. Психология: Журнал Высшей Школь Экономики. 2004. T. 1, № 4. С. 3-26.

9. Тихомиров О. К. Эмоции в структуре мыслительной деятельности. Психология Мышления. Москва: Изд-во МГУ, 1984. С. 87-106.

10. Чебыкин А. Я. Эмоциональная регуляция учебно-познавательной деятельности: монография. Одесса: Изд-во Одесского государственного пед. инта. 1992.168 с

11. Чебикін О. Я. Про методику діагностики емоційної зрілості особистості. Наука і освіта. 1997. №1. C.68-69.

12. Чебикін О. Я. Становлення емоційної зрілості особистості / I. Г. Павлова. Одеса: Наукове видання determinants of the manifestation of emotional intelligence, as well as the psychological characteristics of its probable human typical manifestations.
Південного наукового Центру НАПН України, 2009. $230 \mathrm{c}$.

13. Шпак М. М. Теоретико-методологічні підходи до розуміння феномену емоційного інтелекту особистості. Актуальні проблеми соціології, психології, педагогіки : зб.наук.праць Київського національного університету ім. Т. Г. Шевченко; ред кол. : Судаков та ін. Київ: Логос, 2011. Т. 1. С. 192-199.

14. Bilous R. M., Pysarenko D. O. Psychological peculiarities of student's social maturity. Science and Education. 2017. №7. Pp. 21-31.

15. Chebykin O. Ya., Kosianova O. Yu. Deceitfulness According To The Indicators of Emotional Maturity Methodology and Polygraph Examination. Science and Education. 2016. №2-3. Pp. 106-109.

\section{References}

1. Andreeva, I. N. (2011). Emotional intelligence as a phenomenon of modern psychology [Emotsionalny intellekt kak fenomen sovremennoy psikhologii]. Novopolotsk: PSU [in Russian].

2. Vasiliev, I. A. (1998). Rol intellektualnykh emotsiy $\mathrm{v}$ regulyatsii myslitelnoy deyatelnosti [The role of intellectual emotions in the regulation of mental activity]. Psikhologichesky zhurnal - Psychological Journal, 4(19), 49-60 [in Russian].

3. Weissbach, H., \& Dax, W. (1988). Emotsionalny intellect [Emotional Intelligence]. Moscow: Lick Press [in Russian].

4. Goleman, D. (2011). Emotsionalny intellekt [Emotional Intelligence]. A. P. Isaeva (Transl.). Moscow: AST, Astrel [in Russian].

5. Morgun, V. R. (2010). Emotsiini intelekt u bagatovymirnii strukturi osobystosti [Emotional intelligence in the multidimensional structure of personality]. Postmethodology, 6 (97), 2-14 [in Ukrainian].

6. Nosenko, E. L. (2004). Emotsiinyi intelekt yak sotsialno znachushcha integralna vlastyvist osobistosti 
[Emotional intelligence as a socially significant integral property of personality]. Psikhologiia i suspilstvo - Psychology and society, 4, 95-109 [in Ukrainian].

7. Roberts, R. D. (2004). Emotsionalny intellekt: problemy teorii, izmereniya i primeneniya na praktike [Emotional intelligence: problems of theory, measurement and application in practice]. Psikhologiya: Zhurnal Vysshey Shkoly Ekonomiki - Psychology: Journal of the Higher School of Economics, 4(1), 3-26 [in Russian].

8. Tikhomirov, O. K. (1984). Emotsii v strukture myslitelnoy deyatelnosti. Psikhologiya Myshleniya [Emotions in the structure of mental activity. Psychology of Thinking]. Moscow: Publishing House of Moscow State University, 87-106 [in Russian].

9. Chebykin, A. Ya. (1992). Emotsionalnaya regulyatsiya uchebno-poznavatelnoy deyatelnosti [Emotional regulation of educational and cognitive activities]. Odessa: Publishing House of Odessa State Pedagogical University [in Russian].
10. Chebykin, O. Ya. (1997). Pro metodiku diagnostiki emotsiynoi zrilosti osobistosti [The method of diagnosis of emotional maturity of individual]. Nauka i osvitaScience and Education, 1, 68-69 [in Ukrainian].

11. Chebykin, O. Ya. (2009). Stanovlennia emotsiinoi zrilosti osobistosti [Formation of emotional maturity of the individual]. I. G. Pavlova (Eds.). Odessa: Scientific edition of Southern Scientific Center of the National Academy of Pedagogical Sciences of Ukraine [in Ukrainian].

12. Shpak, M. M. (2011). Teoretiko-metodologichni pidhodi do rozuminnia fenomenu emotsiinogo intelektu osobistosti. Aktualni problemy sotsiolohii, psikhologii, pedagogiki [Theoretical and methodological approaches to understanding the phenomenon of emotional intelligence of individual. Actual problems of Sociology, Psychology, Pedagogy]. (Vol. 1). (pp. 192-199). Kyiv: Logos [in Ukrainian].

\section{Oleksiy Chebykin, Doctor of Psychology, academician of the National Academy of Pedagogical Sciences of Ukraine, The State institution "South Ukrainian National Pedagogical University named after K. D. Ushynsky",} 26, Staroportofrankivska St., Odessa, Ukraine

\section{EMOTIONAL INTELLIGENCE, ITS COGNITIVE AND MENTAL SIGNS AND FUNCTIONS}

An attempt has been made in this paper to single out the cognitive and mental signs of emotional intelligence and their functions in this process. It has been shown that a significant part of specialists, despite the declarative correspondence of this phenomenon to the sphere of emotions and intelligence, analyzes the social intelligence as the subject of its study and its communicative signs, emotional maturity and its components, self-regulation, empathy, expressiveness of emotions, etc. It can be assumed that in this case, the signs of emotional intelligence are replaced by those that relate to the subject of the study of other psychological phenomena. It should be also agreed that all mental phenomena are closely related, especially since emotions are actually integrated into every process. But when the emotional intelligence is chosen as a subject of study, then this should refer to those signs which should be more reflected certain specific features of emotions in the intelligence. It has been proposed to consider emotional intelligence as a psychological property of individual, characterized by the manifestation of complex as though integrated, emotionalcognitive and mental features, due to which it achieves its goal in certain tasks/problems solving in different activities. It can be argued that emotions are more integrated with cognitive activity in emotional intelligence, and intelligence - with mental activity. That is, the features of the functioning of basic (simple) emotions in higher cognitive, integrated with mental activity are probably what can characterize the psychological essence of the content of emotional intelligence. Such higher emotional and cognitive features that accompany this process include surprise, curiosity, inquisitiveness, interest, enthusiasm, inspiration, guess, disappointment, doubt, insight experience, eureka, and others. The manifestation of these signs may be accompanied by certain functions at the level of comfort emotional coloring of the problem-solving process, emotional guidance on how to solve the problem, emotional activation in the form of strengthening or weakening the manifestation of this process, emotional regulation as dynamics of change of movement of the signs in the problemsolving process. A complex of three methods has been created: investigation of signs of emotional intelligence; study of the manifestation of simple emotions in the content of higher emotions attributed to the signs of emotional intelligence; study of the selected functions of signs of emotional intelligence. It has been shown that there is a certain tendency in the manifestation of signs of emotional intelligence, and its integral components of simple emotions in the problem-solving process. It has been revealed that the emotionally positive orientation of the content of such signs of emotional intelligence as curiosity, insight experience, eureka, their connection with joy and comfort functions of emotional guidance, emotional activation and regulation, form the first complex of emotional intelligence. The second complex is formed on the basis of such signs of emotional intelligence as inquisitiveness, guess and doubt. The third one includes curiosity, enthusiasm and disappointment. These complexes can be those specific determinants of the manifestation of emotional intelligence, as well as the psychological characteristics of its typical manifestations in humans.

Keywords: emotions, intelligence, cognitive and mental signs, functions, complexes, signs of emotional intelligence.

Подано до редакиії 12.03.2020 